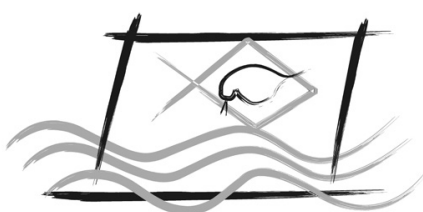

ECOTOX - BRASIL

\title{
Acute toxicity of copper and chromium oxide nanoparticles to Daphnia similis
}

\author{
K.P. Tavares ${ }^{1}$; Á. Caloto-Oliveira ${ }^{2}$; D.S. Vicentini³; S.P. Melegari ${ }^{3}$; W.G. Matias; \\ S. BARBOSA ${ }^{1} \&$ F. KuMmROW ${ }^{4}$ \\ ${ }^{1}$ Institute of Nature Sciences, Federal University of Alfenas, Alfenas, Minas Gerais, Brazil. \\ ${ }^{2}$ Laboratory of Ecotoxicology and Environmental Microbiology, LEAL, Faculty of Technology, \\ State University of Campinas, Limeira, São Paulo, Brazil. \\ ${ }^{3}$ Laboratory of Environmental Toxicology, LABTOX, Department of Sanitary and Environmental Engineering, \\ Federal University of Santa Catarina, Florianópolis, Santa Catarina, Brazil. \\ ${ }^{4}$ Institute of Environmental, Chemical and Pharmaceutical Sciences, Federal University \\ of São Paulo, Diadema, São Paulo, Brazil.
}

(Received January 22, 2014; Accept June 11, 2014)

\begin{abstract}
Copper oxide nanoparticles (CuO NPs) are employed in antifouling paints, and chromium oxide nanoparticles $\left(\mathrm{Cr}_{2} \mathrm{O}_{3} \mathrm{NPs}\right)$ have been used as a green pigment. Their extensive use can contaminate aquatic ecosystems, and the toxicological effects of these NPs to the biota are poorly known. In this study, we evaluated the acute toxicity induced by $\mathrm{CuO}$ and $\mathrm{Cr}_{2} \mathrm{O}_{3} \mathrm{NPs}_{\text {, }}$ comparing with $\mathrm{CuSO}_{4}$ and $\mathrm{Cr}\left(\mathrm{NO}_{3}\right)_{3}$ as $\mathrm{Cu}^{2+}$ and $\mathrm{Cr}^{3+}$ ion source, respectively, using the microcrustacean Daphnia similis. The mean $\mathrm{EC}_{50}-48 \mathrm{~h}$ for $\mathrm{CuO}$ NPs was $0.064 \mathrm{mg} \mathrm{L}^{-1}$ and for $\mathrm{CuSO}_{4}$ was $0.015 \mathrm{mg} \mathrm{L}^{-1}$. CuO NPs tend to agglomerate, which may have reduced the release of $\mathrm{Cu}^{2+}$ in the test medium in relation to $\mathrm{CuSO}_{4}$. The mean $\mathrm{EC}_{50}-48 \mathrm{~h}$ for $\mathrm{Cr}_{2} \mathrm{O}_{3} \mathrm{NPs}$ was $6.74 \mathrm{mg}$ $\mathrm{L}^{-1}$ and for $\mathrm{Cr}\left(\mathrm{NO}_{3}\right)_{3}$ was $11.98 \mathrm{mg} \mathrm{L}^{-1}$. The reduced size of the $\mathrm{Cr}_{2} \mathrm{O}_{3} \mathrm{NPs}(15-30 \mathrm{~nm})$ and the higher zeta potential may have contributed to the higher stability in suspension and less potential for agglomeration, partially explaining the higher toxicity of NPs in relation to $\mathrm{Cr}\left(\mathrm{NO}_{3}\right)_{3}$. After the tests, we observed morphological damages such as increase in fat droplets, internal organ exposure and partially disintegration in organisms exposed to all tested substances, NPs or the salts.
\end{abstract}

Keywords: Acute toxicity tests, Daphnia similis, Metal oxide nanoparticles, Microcrustaceans, Nanotoxicology.

\section{INTRODUCTION}

Metal oxide nanoparticles (NPs) are already manufactured in large scale for both industrial and household use, and are incorporated into a wide range of products such as sunscreens, paints, construction materials, coatings, catalysts and cosmetics (Aruoja et al., 2009; Keller et al., 2010; Hanna et al., 2013). Copper oxide (CuO) NPs have potential to replace noble metal catalysts for carbon monoxide oxidation and $\mathrm{CuO}$ NPs suspension (nanofluid) has excellent thermal conductivity for it to be used as a heat transfer fluid in machine tools (Buffet et al., 2011). Furthermore,
$\mathrm{CuO}$ NPs has been used for antimicrobial textiles (Gabbay et al., 2006), gas sensors, photovoltaic cells, air and liquid filtration (Sousa \& Teixeira, 2013), and as antifouling paints of boats, thus representing an important source of aquatic ecosystems contamination (Melegari et al., 2013).Chromium oxide $\left(\mathrm{Cr}_{2} \mathrm{O}_{3}\right)$ NPs has also attracted considerable attention in recent years. A wide range of applications such as coating materials for thermal protection, wear resistance, humidity sensing and refractory characteristics have been reported (Makhlouf et al., 2013). In addition, this type of NP has been used in green pigment composition (Gibot \& Vidal, 2010). As result of the increased use and production of NPs over

*Corresponding author: Fábio Kummrow; e-mail: fkummrow@unifesp.br 
the last years has led to their release in aquatic environments (Kahru et al., 2008; Hanna et al., 2013).

However, while the novel properties of NPs are increasingly studied, little information is available about their interactions with aquatic organisms (Kahru et al., 2008). Additionally, transformations of NPs, such as dissolution, agglomeration, sedimentation, or change of surface moieties, could greatly affect the pathway and extent of NPs environmental fate (Maurer-Jones et al., 2013).When added to water, metal NPs can aggregate, sediment out of the water column, adsorb to nutrients, and disassociate to release soluble metal ions (Griffitt et al., 2009). For all these reasons, factors such as NPs aggregation, size and surface properties play a crucial role in NPs toxicity because they affect the bioavailability of such materials (Sousa \& Teixeira, 2013), and so the characterization of NPs that will be submitted to ecotoxicological evaluation is a fundamental step. Moreover, the knowledge of biological effects, target sites, and especially the modes of action of the engineered particles seems to be unknown yet (Manusadžianas et al., 2012).

$\mathrm{CuO}$ NPs were identified as being important in ecotoxicological assays due to their relatively low dissolution rate but their potentially high toxicity towards organisms (Buffet et al., 2011). Several studies have demonstrated toxicity of $\mathrm{CuO}$ NPs to aquatic organisms, including Allivibrio fischeri, Daphnia magna, Hediste diversicolor, Pseudokirchneriella subcapitata, Scrobicularia plana, Thamnocephalus platyurus (Heinlaan et al., 2008; Aruoja et al., 2009; Kahru \& Dubourguier, 2010; Buffet et al., 2011; Isani et al., 2013), but there is no consensus yet, among authors, regarding the toxic effect observed to be associated with the NPs themselves or just with the release of $\mathrm{Cu}$ ions in the test media.

Thus, it is necessary to characterize correctly their effects on aquatic organisms, considering the high toxicity before demonstrated by copper ions to aquatic organisms (Kahru \& Dubourguier, 2010). On the order hand, limited data are available in the literature on $\mathrm{Cr}_{2} \mathrm{O}_{3} \mathrm{NPs}$ toxicity. Annarao et al. (2008) examined the distribution of $\mathrm{Cr}_{2} \mathrm{O}_{3}$ NPs in rats and found that its absorption through the skin was efficient and NPs was evenly distributed in the tissues and muscles. Vajpayee et al. (2011) evaluated the phytotoxic effects of $\mathrm{Cr}_{2} \mathrm{O}_{3}$ NPs to wheat (Triticumae stivum), and observed that there was inhibition of seed germination and seedling growth in concentration-dependent manner. However, studies published in the international literature on the toxicity of these types of NPs to aquatic organisms are scarce. Lin et al. (2012) used zebrafish (Danio rerio) embryos and demonstrated that $\mathrm{Cr}_{2} \mathrm{O}_{3}$ NPs interfered in embryo hatching.

The aim of this work was to evaluate the acute toxicity of $\mathrm{CuO}$ and $\mathrm{Cr}_{2} \mathrm{O}_{3} \mathrm{NPs}$, comparing with $\mathrm{CuSO}_{4}$ and $\mathrm{Cr}\left(\mathrm{NO}_{3}\right)_{3}$ as $\mathrm{Cu}^{2+}$ and $\mathrm{Cr}^{3+}$ ion source, respectively, using Daphnia similis. The choice of $D$. similis as test organism is based on your reproduction by parthenogenesis, ease of cultivation in the laboratory, simple handling, sensitivity to wide range of pollutants, life and reproductive short cycle and, for being an internationally standardized testing organism (Knie \& Lopes, 2004; Paschoalino et al., 2010). Furthermore, daphnids are considered a keystone species in aquatic toxicology because they are filter-feeders and are able to ingest NPs (Artal et al., 2013).Tests employing Daphnia have been used to evaluate the nanomaterials ecotoxicity, due to be important links in the food chain from algae consumed by them, and the fish that are predators (Paschoalino et al., 2010).They have also been proposed as a model organism for the ecotoxicological testing of nanomaterials (Paschoalino et al., 2010; Artal et al., 2013).

\section{MATERIAL AND METHODS}

\section{Materials}

Due the high heterogeneity of commercial NPs, we choose to synthesize the NPs of interest in this study. The following materials were used to synthesized the evaluated NPs: copper sulfate hydrate $\left(\mathrm{CuSO}_{4} .5 \mathrm{H}_{2} \mathrm{O} ; 98 \%\right)$, sodium carbonate $\left(\mathrm{Na}_{2} \mathrm{CO}_{3} ; 99 \%\right)$, chromium nitrate hydrate $\left(\mathrm{Cr}\left(\mathrm{NO}_{3}\right)_{3} \cdot 9 \mathrm{H}_{2} \mathrm{O}\right.$; $97 \%)$ and sodium hydroxide $(\mathrm{NaOH} ; \geq 97 \%)$ purchased from Vetec $^{\circledR}$ (Duque de Caxias, RJ, Brazil), and distilled water. All chemicals were analytical grade and were used as received.

\section{$\mathrm{CuO}$ NPs synthesis}

$\mathrm{CuO}$ NP was prepared via direct thermal decomposition method, adapted from Das et al. (2013) to improve the reaction yield and purity of NPs, as well as facilitates the synthesis procedure. An excess of $\mathrm{Na}_{2} \mathrm{CO}_{3}$ was used, instead of 1 eq., and the final product was separated by centrifugation, instead of filtration. The precursor, $\mathrm{Cu}_{4}\left(\mathrm{SO}_{4}\right)(\mathrm{OH})_{6}$, was synthesized by adding $100 \mathrm{~mL}$ of a $60 \mathrm{mmol} \mathrm{Na}_{2} \mathrm{CO}_{3}$ solution to $100 \mathrm{~mL}$ of a $50 \mathrm{mmol} \mathrm{CuSO}_{4} .5 \mathrm{H}_{2} \mathrm{O}$ solution, and the mixture was ultrasonicated in a ultrasonic cell disruptor (Unique - 100 $\mathrm{W}, 99 \%$ of the maximum power) for $60 \mathrm{~min}$ at $60{ }^{\circ} \mathrm{C}$. The precipitate produced was separated by centrifugation and washed several times with warm distilled water to remove any possible remaining ions in the final product. Then, the precipitate was dried in an oven at $70{ }^{\circ} \mathrm{C}$ for $12 \mathrm{~h}$. Finally, it was placed in a preheated muffle furnace at $600{ }^{\circ} \mathrm{C}$ for decomposition. After $2 \mathrm{~h}$, the $\mathrm{CuO}$ NPs were removed from the furnace and allowed to cool to room temperature, and the resulting dark brown powder was ground and sieved.

\section{$\mathrm{Cr}_{2} \mathrm{O}_{3} \mathrm{NPs}$ synthesis}

$\mathrm{Cr}_{2} \mathrm{O}_{3}$ NPs were synthesized using the thermal degradation methodology of $\mathrm{Cr}(\mathrm{OH})_{3}$ adapted from Bañobre-López et al. (2003), to facilitate the synthesis procedure and to avoid the oxidation of $\mathrm{Cr}^{3+}$ to $\mathrm{Cr}^{6+}$. The temperature of drying $\mathrm{Cr}(\mathrm{OH})_{3}$ was $90{ }^{\circ} \mathrm{C}$ instead of $65^{\circ} \mathrm{C}$, and the final product was separated by centrifugation, instead of filtration. $21 \mathrm{mmol}$ $\mathrm{Cr}\left(\mathrm{NO}_{3}\right)_{3} \cdot 9 \mathrm{H}_{2} \mathrm{O}$ and $50 \mathrm{mmol} \mathrm{NaOH}$ were added to $100 \mathrm{~mL}$ of distilled water and stirred for $30 \mathrm{~min}$. The product was 
separated by centrifugation and washed several times with distilled water. The $\mathrm{Cr}(\mathrm{OH})_{3}$ was dried in an oven for $24 \mathrm{~h}$ at $90{ }^{\circ} \mathrm{C}$. Finally the product was calcined at $400{ }^{\circ} \mathrm{C}$ for $3 \mathrm{~h}$ for obtain $\mathrm{Cr}_{2} \mathrm{O}_{3}$ NPs.

\section{Characterizations of NPs}

All synthesized NPs were characterized by X-ray diffractograms (XRD), which were measured over the angular range of $2 \theta=20^{\circ}-80^{\circ}$ using a Philips $X^{\prime}$ 'Pertdiffractometer equipped with a copper tube (CuK $\alpha, \lambda=1.54056 \AA)$. Images revealing the morphologies and sizes of the NPs were obtained using a transmission electron microscope (TEM; JEM-1011 TEM microscope). The zeta potential ( $\zeta)$ of the NPs was measured using a Malvern Zetasizer Nano ZS (ZEN 3600 model). The samples for zeta potential and transmission electron microscope were prepared in ultrapure water (UW) $\left(1 \mathrm{~g} \mathrm{~L}^{-1}\right)$.

\section{Ecotoxicity tests}

Suspensions of $\mathrm{CuO}\left(100 \mathrm{mg} \mathrm{L}^{-1}\right)$ and $\mathrm{Cr}_{2} \mathrm{O}_{3}(1000 \mathrm{mg}$ $\left.\mathrm{L}^{-1}\right)$ NPs were prepared in mineral water and sonicated for $30 \mathrm{~min}$ in an ultrasonic bath (Colle Palmer 8891). Both NPs were initially tested at logarithmic scale of concentration (concentrations ranging $0.001-100 \mathrm{mg} \mathrm{L}^{-1}$ ). Based on the preliminary results of these tests were chosen the final test concentrations. $\mathrm{CuO}$ NPs were tested at concentrations 0.02 ; 0.04; 0.06; 0.08; 0.10; 0.12 and $0.14 \mathrm{mg} \mathrm{L}^{-1} . \mathrm{Cr}_{2} \mathrm{O}_{3}$ NPs were tested at concentrations $10,15,20,25,30,35$ and $40 \mathrm{mg} \mathrm{L}^{-1}$.

For comparison, solutions of the salts $\left(\mathrm{CuSO}_{4}\right.$ and $\left.\mathrm{Cr}\left(\mathrm{NO}_{3}\right)_{3}\right)$ used in the NPs synthesis were tested as a source of $\mathrm{Cu}^{2+}$ and $\mathrm{Cr}^{3+}$, respectively. Both inorganic salts were initially tested at logarithmic scale of concentration (concentrations ranging $0.001-500 \mathrm{mg} \mathrm{L}^{-1}$ ). Based on the preliminary results of these tests were chosen the final test concentrations. $\mathrm{CuSO}_{4}$ was tested using the nominal concentrations of $0.02 ; 0.04$; 0.06 ; $0.08 ; 0.10 ; 0.12$ and $0.14 \mathrm{mg} \mathrm{L}^{-1}$, while $\mathrm{Cr}\left(\mathrm{NO}_{3}\right)_{3}$ was tested using nominal concentrations of $30,60,90,120,150$

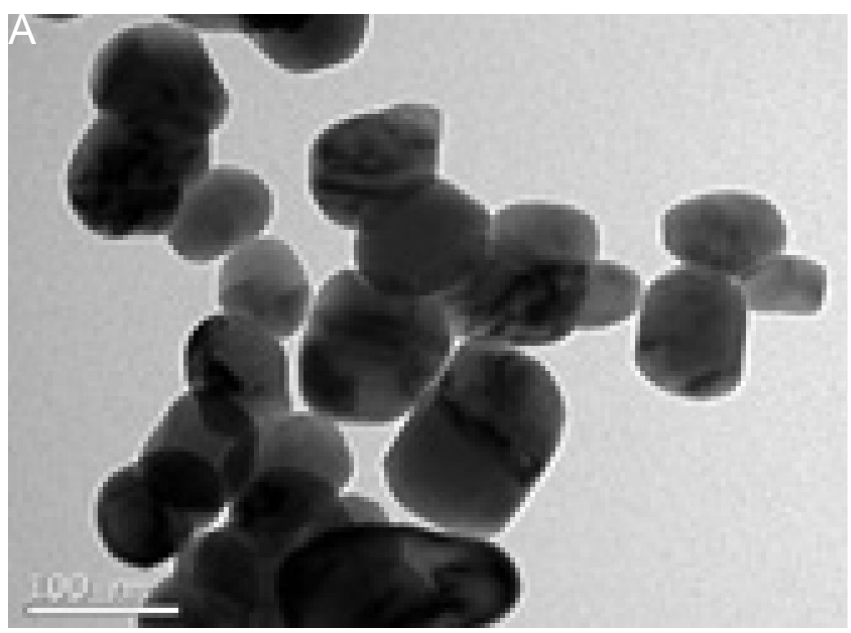

and $180 \mathrm{mg} \mathrm{L}^{-1}$. The tests were performed immediately after the preparation of the suspensions and solutions.

D. similis stock cultures were kept according to procedure NBR 12713 (ABNT, 2009). The sensitivity of the D. similis culture was monitored monthly with sodium chloride $(\mathrm{NaCl}$, Sigma Aldrich, $\geq 99 \%$ purity), as a reference substance, and the culture was used if the results were within the range expected toxicity whose $\mathrm{EC}_{50}-48 \mathrm{~h}$ should be between 1.6 and $3.6 \mathrm{~g}$ $\mathrm{L}^{-1}$ (CETESB, 1994). Acute toxicity tests were performed according to the NBR 12713 (ABNT, 2009). For each of four replicates five organisms 6 to 24-h-old were exposed during 48 $\mathrm{h}$ in $10 \mathrm{~mL}$ of each test concentrations under static conditions at $20 \pm 2{ }^{\circ} \mathrm{C}$ in the dark. After exposure, immobilized organisms were counted and the $\mathrm{EC}_{50}-48 \mathrm{~h}$ estimated by the TrimmedSpearman Karber method (Hamilton et al., 1977). Tests were considered acceptable if $D$. similis immobility in negative controls did not exceed 10\% (maximum of two organisms).

\section{RESULTS AND DISCUSSION}

\section{Characterizations of NPs}

TEM images of the synthesized $\mathrm{CuO}$ and $\mathrm{Cr}_{2} \mathrm{O}_{3}$ NPs are shown in Figure 1 ( $a$ and b). The TEM image in Figure 1a shows that the NPs are nearly spherical, with diameters ranging from 50 to $100 \mathrm{~nm}$. Figure $1 \mathrm{~b}$ shows an irregular morphology, with rare scattered clusters and NPs with sizes ranging between 15 and $30 \mathrm{~nm}$.

The crystalline structures of NPs were examined by XRD (Figure 2 (a) and (b)). For CuO NPs the diffraction peaks from are consistent with the standard structure and can be indexed to the monoclinic phase of $\mathrm{CuO}$ (JCPDS No. 89-5898) (Massarotti et al., 1998). The results indicated that the products are consisted of pure phase. Different peaks were observed at $2 \theta=32.50^{\circ}(110), 35.42^{\circ}(002), 38.70^{\circ}(111), 48.72^{\circ}$ (202), $53.49^{\circ}(020), 58.27^{\circ}(202), 61.52^{\circ}(113), 66.22^{\circ}(311)$ and $68.12^{\circ}(220)$ corresponds to several planes of $\mathrm{CuO}$ NP. This confirms the formation of $\mathrm{CuO}$ NPs. For $\mathrm{Cr}_{2} \mathrm{O}_{3} \mathrm{NPs}$ the

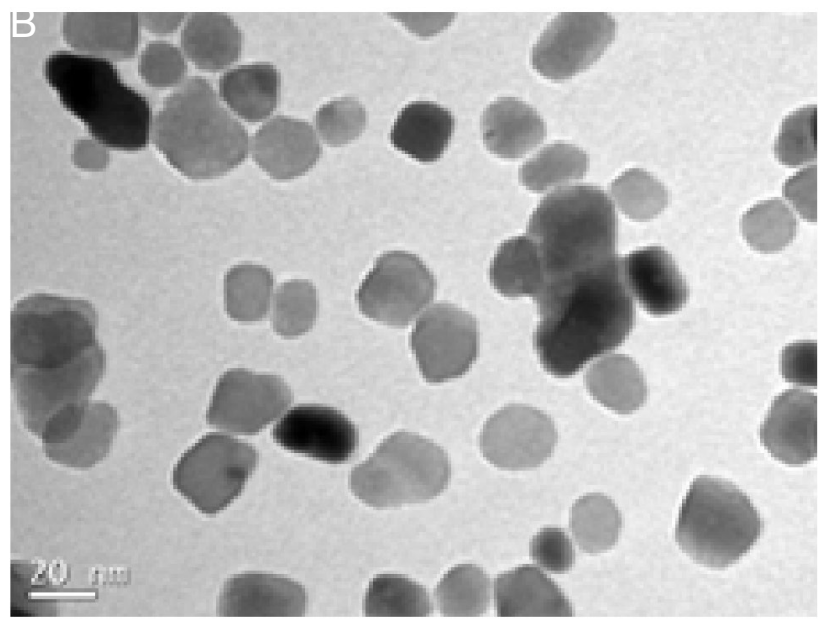

Figure 1 - TEM image of CuO NPs (a) and $\mathrm{Cr}_{2} \mathrm{O}_{3}$ NPs (b). 

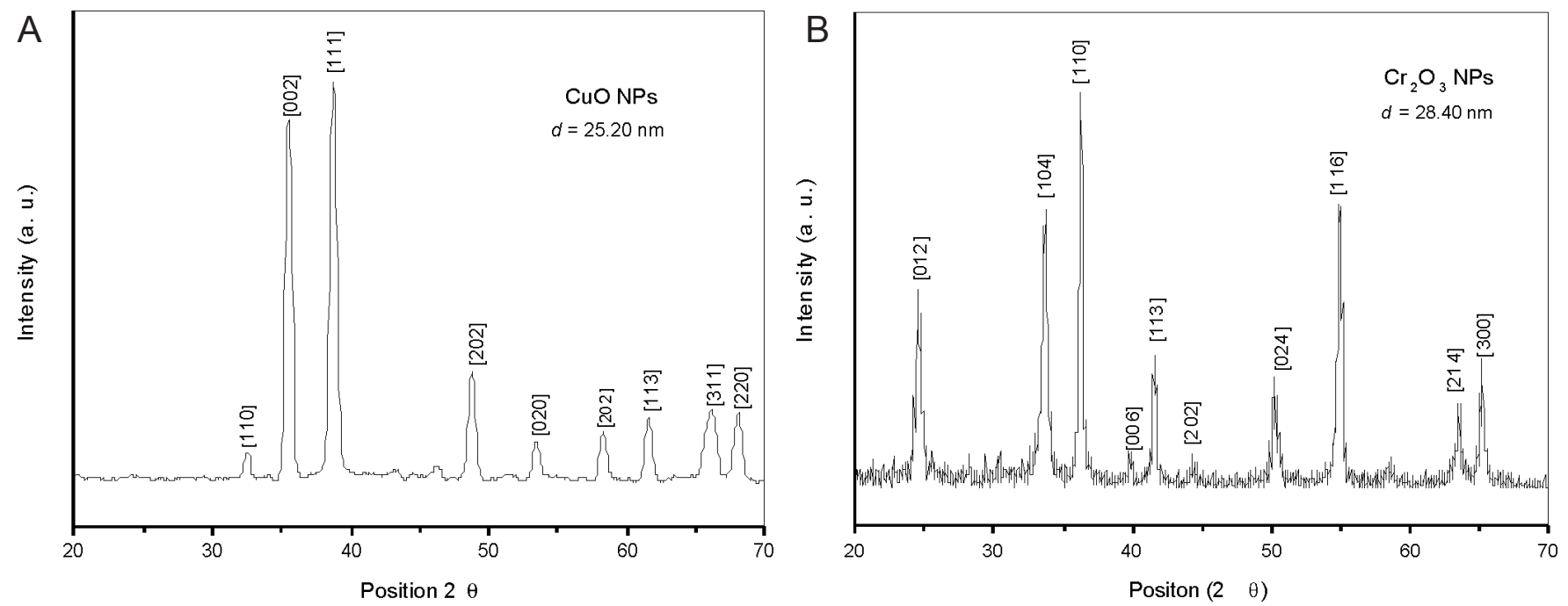

Figure 2 - XRD of CuO NPs (a) and of $\mathrm{Cr}_{2} \mathrm{O}_{3}$ NPs (b).

diffraction peaks from are consistent with the crystal structure rhombohedral (space group 167, R-3c) and hexagonal lattice parameters (JCPDS No. 082-1484). Different peaks were observed at $2 \theta=24.65^{\circ}(012), 33.70^{\circ}(104), 36.32^{\circ}(110)$, $39.86^{\circ}(006), 41.46^{\circ}(113), 44.28^{\circ}(202), 50.28^{\circ}(024), 54.86^{\circ}$ (116), $63.32^{\circ}(214)$ and $65.27^{\circ}(300)$ corresponds to several planes of $\mathrm{Cr}_{2} \mathrm{O}_{3}$ NPs. The crystallite size based on X-ray peak broadening was estimated using Debye-Scherrer's equation (Equation 1) (El-Trass et al., 2012):

$$
d(\AA)=\frac{k \lambda}{\beta \cos \theta}
$$

where $k$ is an empirical constant equal to $0.9, \lambda$ is the wavelength of the X-ray source (1.5405 $\AA$ ), $\beta$ is the full width at half maximum of the diffraction peak, and $\theta$ is the angular position of the peak. The average value calculated for the crystallite size for CuO NPs is $25.2 \mathrm{~nm}$ and for $\mathrm{Cr}_{2} \mathrm{O}_{3} \mathrm{NPs}$ is $28.40 \mathrm{~nm}$.

Zeta potential value for $\mathrm{CuO}$ NPs suspension in ultrapure water was $-11.73 \mathrm{mV}$, and the $\mathrm{pH}$ of the suspension was 6.07 . The measure of zeta potential of $\mathrm{Cr}_{2} \mathrm{O}_{3} \mathrm{NPs}$ was $-19.65 \mathrm{mV}$ and $\mathrm{pH}=6.87$. Zeta potential is a common indicator of surface charge, which is the electrical potential at the surface of a sphere that includes the particle and adjacent water molecules that travel with the particle during its motion. A common rule of thumb is that the zeta potential must be $>30 \mathrm{mV}$ or $<-30 \mathrm{mV}$ for repulsion to be sufficiently strong to avoid agglomeration (Oberdörster et al., 2013).

The zeta potential indicates the stability of NPs in solution. The higher the value of the zeta potential greater will be the stability of NPs. These results indicate that $\mathrm{Cr}_{2} \mathrm{O}_{3}$ is more stable in solution than $\mathrm{CuO}$ and both NPs exhibit $\mathrm{pH}$ within the range suitable (5-9) to perform toxicological testing.

\section{Ecotoxicity tests}

$\mathrm{EC}_{50}-48 \mathrm{~h}$ values were determined from the means of results from three independent tests. Since the literature suggests that the toxicity of metal NPs is mainly related to the release of the metallic ions (Heinlaan et al., 2008; Aruoja et al., 2009; Perreault et al., 2014), the $\mathrm{EC}_{50}-48 \mathrm{~h}$ were corrected for mass of cooper present in the NPs as well as in the $\mathrm{CuSO}_{4}$ and for mass of chromium present in to $\mathrm{Cr}_{2} \mathrm{O}_{3} \mathrm{NPs}$ and $\mathrm{Cr}\left(\mathrm{NO}_{3}\right)_{3}$.

$\mathrm{EC}_{50}-48 \mathrm{~h}$ mean for $\mathrm{CuO} \mathrm{NPs}$ was $0.064 \mathrm{mg} \mathrm{L}^{-1}$ and for $\mathrm{CuSO}_{4}$ was $0.015 \mathrm{mg} \mathrm{L}^{-1}$ (Table 1). CuO NPs were four times less toxic than the copper sulfate salt (values corrected by mass of copper). $\mathrm{EC}_{50}-48 \mathrm{~h}$ of $\mathrm{CuSO}_{4}$ obtained for $D$. similis is in agreement to the results of Bertolleti et al. (1992), $0.023 \mathrm{mg}$ $\mathrm{L}^{-1}$. Besides different species of Daphnia present differences in the sensibility to metals, Arauco et al. (2005) compare the toxicity of $\mathrm{CuSO}_{4}$ using three different species of Daphnia. The authors obtained similar values of $\mathrm{CuSO}_{4} \mathrm{EC}_{50}-48 \mathrm{~h}$ for $D$. similis and D. magna (0.0447 and $0.0426 \mathrm{mg} \mathrm{L}^{-1}$ respectively values of $\mathrm{EC}_{50}-48 \mathrm{~h}$ without correction for $\mathrm{Cu}$ mass). Rodgher et al. (2010) evaluated the response of D. similis to cadmium and chromium and concluded that this specie is as sensitive to metals as other standardized Daphnia species and behaves as an ideal test organism for ecotoxicological assessments. Based on this data and in the lack of toxicity data for $\mathrm{CuO}$ NPs to $D$. similis, we compare our results with data from $D$. magna available in the literature.

Table $1-\mathrm{EC}_{50}-48 \mathrm{~h}$ values obtained for the three independent tests performed with $\mathrm{CuO} N \mathrm{NPs}_{\text {and }} \mathrm{CuSO}_{4}$ using $D$. similis.

\begin{tabular}{lcccc}
\hline & \multicolumn{2}{c}{$\mathbf{C u O ~ N P s}$} & \multicolumn{2}{c}{$\mathbf{C u S O}_{4}$} \\
Test & $\begin{array}{c}\mathbf{E C}_{\mathbf{5 0}}{ }^{*} \mathbf{4 8 h} \\
\left(\mathbf{m g ~ L}^{-1}\right)\end{array}$ & $\mathbf{C I ~ 9 5 \% * *}$ & $\begin{array}{c}\mathbf{E C}_{50}-\mathbf{4 8 h} \\
\left(\mathbf{m g ~ L}^{-1}\right)\end{array}$ & $\mathbf{C I ~ 9 5 \%}$ \\
\hline 1 & 0.051 & $0.05-0.06$ & 0.010 & $0.01-0.01$ \\
2 & 0.065 & $0.06-0.07$ & 0.012 & $0.01-0.01$ \\
3 & 0.077 & $0.07-0.08$ & 0.010 & $0.01-0.01$ \\
\hline Mean & 0.064 & & 0.010 & \\
Standard & 0.013 & & 0.001 & \\
deviation & & & 11.540 & \\
CV (\%)*** & 20.350 & & & \\
\hline
\end{tabular}

$* \mathrm{EC}_{50}-$ Effective concentration $50 \%$

** CI $95 \%$ - Confidence interval of $95 \%$

*** Coefficient of variation 
$\mathrm{EC}_{50}-48 \mathrm{~h}$ values for $\mathrm{CuO} \mathrm{NPs}$ and $\mathrm{CuSO}_{4}$ obtained in this work were lower than values available in the literature for $D$. magna. Heinlaan et al. (2008) compare the toxicity of CuO NPs with particle size $\sim 30 \mathrm{~nm}$ and $\mathrm{CuSO}_{4}$ obtaining $\mathrm{EC}_{50}-48 \mathrm{~h}$ of 2.6 $\mathrm{mg} \mathrm{L}^{-1}$ for $\mathrm{CuO} \mathrm{NPs}$ and $0.07 \mathrm{mg} \mathrm{L}^{-1}$ for $\mathrm{CuSO}_{4}$. Blinova et al. (2010) also compare the toxicity of $\mathrm{CuO}$ NPs with $\mathrm{CuSO}_{4}$ in natural river waters samples collected in six different sampling sites. The objective of the authors was to compare the influence of artificial freshwater and natural waters in the toxicity of the NPs. The authors obtained $\mathrm{EC}_{50}-48 \mathrm{~h}$ ranging from 92.7 to $>$ $200 \mathrm{mg} \mathrm{L}^{-1}$ for $\mathrm{CuO} \mathrm{NPs}$ and 0.24 to $0.92 \mathrm{mg} \mathrm{L}^{-1}$ to $\mathrm{CuSO}_{4}$. The lower toxicity observed in river water samples in comparison to the test media was attributed to the presence of organic matter that can strongly complex to $\mathrm{Cu}$ and reduce the bioavailability of $\mathrm{Cu}$ ions (Blinova et al., 2010).

Copper sulfate salt was more toxic than the $\mathrm{CuO} N \mathrm{NP}$ for both D. similis and D. Magna (Heinlaan et al., 2008; Blinova et al., 2010). The same behavior was observed to Oncorhynchus mykiss (Isani et al., 2013) and Lemna gibba (Perreault et al., 2014). The higher toxicity of the $\mathrm{CuSO}_{4}$ is associated to the greater bioavailability of $\mathrm{Cu}$ ions in the test media in comparison to the release of $\mathrm{Cu}$ ions from the $\mathrm{CuO}$ NPs. Other important factor is the aggregation of the NPs that can decrease the release of $\mathrm{Cu}$ ions (Perreault et al., 2014). In this work the lower toxicity of the $\mathrm{CuO}$ NPs in relation of $\mathrm{CuSO}_{4}$ may be related also by $\mathrm{CuO}$ NPs tendency to agglomerate, which may have reduced the release of $\mathrm{Cu}^{2+}$ in the test medium and also a lower intake of the agglomerates by $D$. similis. This tendency to agglomeration and coagulation was observed during the preparation of the suspension and by the low zeta potential $(-11.73 \mathrm{mV})$.

Although the evaluation of morphological parameters is not part of the acute toxicity tests with $D$. similis, during the evaluation of the immobility of tests organisms, it was also observed an increase in the size of fat droplets as a response to exposure to NPs (Figure 3b) compared to control (Figure 3a). Artal et al. (2013) also reported small bubbles under the carapace of $D$. similis exposed the silver nanowires that were similar to those observed in this work. The organisms exposed to $\mathrm{CuSO}_{4}$ suffered great damage with exposure of internal organs (Figure $3 \mathrm{c}$ ).

Although the toxicity of $\mathrm{CuO}$ NPs was lower than that of the $\mathrm{CuSO}_{4}$ salt, the values of $\mathrm{EC}_{50}-48 \mathrm{~h}$ had become very low, indicating high toxicity. According to Directive 67/548/EEC, the main European Union legislation on chemical safety, substances that exhibit $\mathrm{EC}_{50}$ less than $1 \mathrm{mg} \mathrm{L}^{-1}$ are classified as very toxic (Kahru \& Ivask, 2012), indicating that the $\mathrm{CuO}$ NPs and $\mathrm{CuSO}_{4}$ may offer potential risks to aquatic biota.

Until the finishing of this manuscript, few studies investigated the chromium NPs toxicity. Lin et al. (2012) investigated the toxicity of chromium NPs to aquatic organisms using $D$. rerio. This study has indicated that $\mathrm{Cr}_{2} \mathrm{O}_{3}$ NPs could interfere with embryo hatching by a chelator-sensitive mechanism that involves ligation of critical histidine in the ZHE1 (metalloprotease, responsible for degradation of the chorionic membrane) center by the shed metal ions. Moreover, Horie et al. (2011) demonstrated that $\mathrm{Cr}_{2} \mathrm{O}_{3}$ NPs have a high cytotoxic potential to human keratinocyte $\mathrm{HaCaT}$ cells.

The mean $\mathrm{EC}_{50}-48 \mathrm{~h}$ for $\mathrm{Cr}_{2} \mathrm{O}_{3}$ NPs was $6.74 \mathrm{mg} \mathrm{L}^{-1}$ and for $\mathrm{Cr}\left(\mathrm{NO}_{3}\right)_{3}$ was $11.98 \mathrm{mg} \mathrm{L}^{-1}$ (Table 2). $\mathrm{Cr}_{2} \mathrm{O}_{3}$ NPs were approximately two times more toxic that the solution of $\mathrm{Cr}\left(\mathrm{NO}_{3}\right)_{3}$. For the $\mathrm{Cr}_{2} \mathrm{O}_{3} \mathrm{NPs}$ the toxicity cannot completely be explained by the $\mathrm{Cr}^{3+}$ ions release. The reduced size of the $\mathrm{Cr}_{2} \mathrm{O}_{3} \mathrm{NPs}(15-30 \mathrm{~nm})$ and the higher zeta potential may have contributed to the observed toxicity. The tested $\mathrm{Cr}_{2} \mathrm{O}_{3} \mathrm{NPs}$ were more stable in suspension and have less agglomeration potential. Thus, in addition to chromium released in the test medium, the NPs present in the D. similis gut may have acted as a direct source of release of $\mathrm{Cr}$ ions to the test organism tissues. Hund-Rinke \& Simon (2006) found that particles with smaller diameters are more easily ingested by D. magna, without any selective mechanism. However, larger particles are more difficult to be processed by the Daphnia (Baudo, 1987), thereby avoiding that the NPs reach the filter chamber.
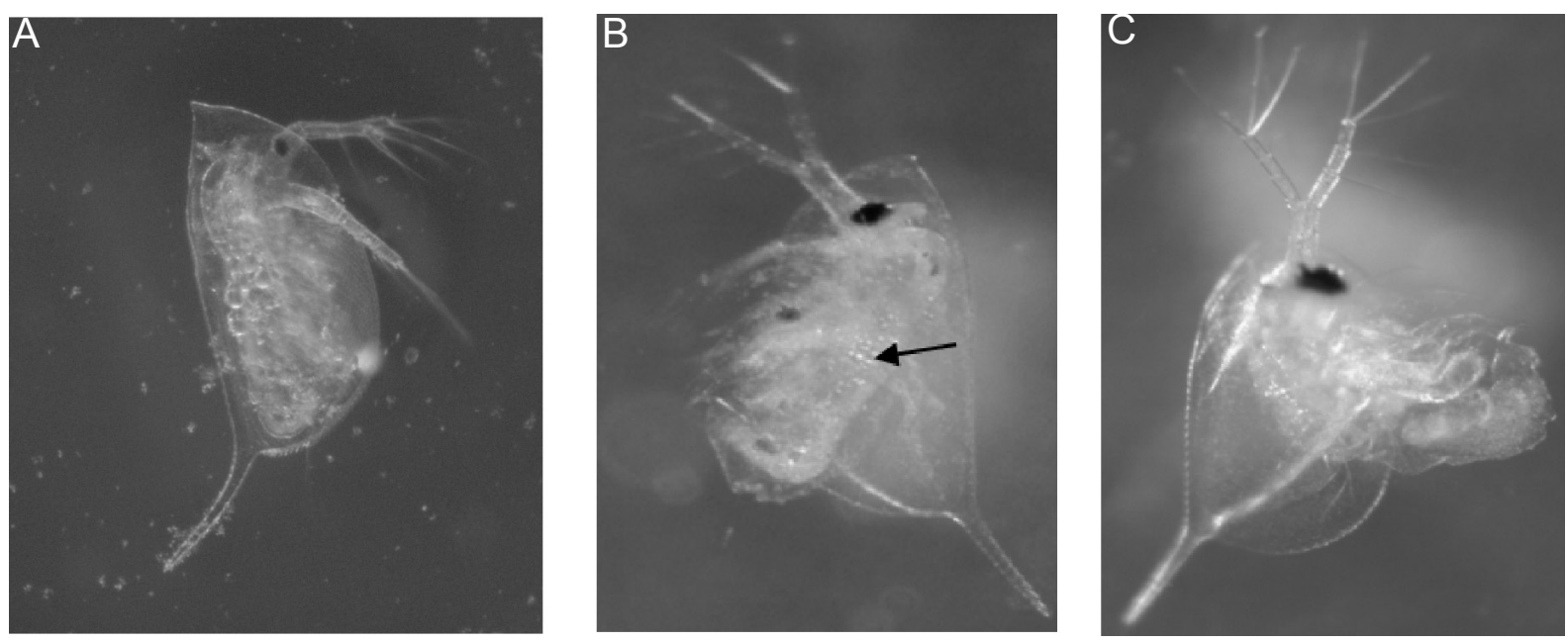

Figure 3 - D. similis at control (a), D. similis after exposure to CuO NPs (b), and the arrow indicate increases in the size of lipid droplets, and D. similis after exposure to $\mathrm{CuSO} 4$ (c).. 
Table $2-\mathrm{EC}_{50}-48 \mathrm{~h}$ values obtained for the three independent tests performed with $\mathrm{Cr}_{2} \mathrm{O}_{3} \mathrm{NPs}$ and $\mathrm{Cr}\left(\mathrm{NO}_{3}\right)_{3}$ using $D$. similis.

\begin{tabular}{|c|c|c|c|c|}
\hline \multirow[b]{2}{*}{ Test } & \multicolumn{2}{|c|}{$\mathrm{Cr}_{2} \mathrm{O}_{3} \mathrm{NPs}$} & \multicolumn{2}{|c|}{$\mathrm{Cr}\left(\mathrm{NO}_{3}\right)_{3}$} \\
\hline & $\begin{array}{c}\mathrm{EC}_{50}{ }^{*}-48 \mathrm{~h} \\
\left(\mathrm{mg} \mathrm{L}^{-1}\right)\end{array}$ & CI 95\%** & $\begin{array}{r}\mathrm{EC}_{50}-48 \mathrm{~h} \\
\left(\mathrm{mg} \mathrm{L}^{-1}\right)\end{array}$ & CI 95\% \\
\hline 1 & 6.53 & $5.95-7.17$ & 12.26 & $11.17-13.47$ \\
\hline 2 & 6.73 & $5.76-7.88$ & 11.03 & $9.12-13.33$ \\
\hline 3 & 6.96 & $6.51-7.22$ & 12.67 & $11.19-14.34$ \\
\hline Mean & 6.74 & & 11.98 & \\
\hline $\begin{array}{l}\text { S t a n d a r d } \\
\text { deviation }\end{array}$ & 0.21 & & 0.85 & \\
\hline $\mathrm{CV}(\%)^{* * *}$ & 3.20 & & 6.96 & \\
\hline
\end{tabular}

Organisms exposed to $\mathrm{Cr}_{2} \mathrm{O}_{3}$ NPs were evaluated after the end of the test, and we could observe that the $D$. similis were partially disintegrated and presented a dark material inside the bodies (Figure 4a), suggesting the intake of the tested NPs. We also observed blue spots in the organisms exposed to $\mathrm{Cr}\left(\mathrm{NO}_{3}\right)_{3}$, probably due to deposition of chromium nitrate on the carapace of $D$. similis (Figure $4 \mathrm{~b}$ ).

Some $\mathrm{EC}_{50}-48 \mathrm{~h}$ values for trivalent chromium have been reported for invertebrate species. Caloto-Oliveira (2007) evaluated the toxicity of potassium dichromate to $D$. similis and the $\mathrm{EC}_{50}-48 \mathrm{~h}$ obtained was $0.081 \mathrm{mg} \mathrm{L}^{-1}$ (corrected value by chromium mass). To D. magna, the range of $\mathrm{EC}_{50}-48 \mathrm{~h}$ obtained to chromic nitrate ranging 2 - $58.7 \mu \mathrm{g} \mathrm{L}^{-1}$ (USEPA, 1980), varying according to the hardness of the water.

Substances with $\mathrm{EC}_{50}$ value ranging $1-10 \mathrm{mg} \mathrm{L}^{-1}$ are considered toxic in accordance with Directive 67/548/EEC and dangerous when $\mathrm{EC}_{50}$ value ranging $10-100 \mathrm{mg} \mathrm{L}^{-1}$ (Kahru \& Ivask, 2012). Thus, $\mathrm{Cr}_{2} \mathrm{O}_{3} \mathrm{NP}$ and chromium nitrate can be considered as toxic and dangerous, respectively.

\section{CONCLUSIONS}

Both NPs tested showed toxicity to D. similis, but with distinct behaviors. While the toxicity of CuO NPs appears is primarily associated with the release of $\mathrm{Cu}$ ions in the test
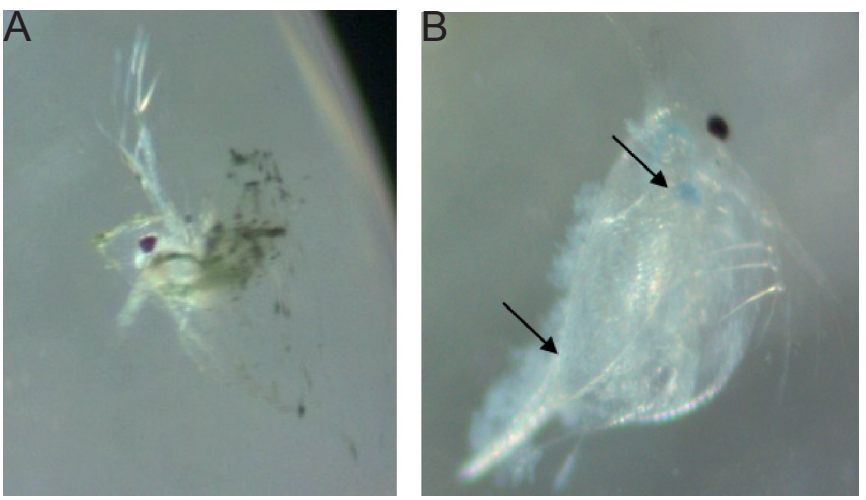

Figure 4 - D. similis after exposure to $\mathrm{Cr}_{2} \mathrm{O}_{3} \mathrm{NPs}$ (a) and $\mathrm{Cr}\left(\mathrm{NO}_{3}\right)_{3}(\mathrm{~b})$, and the arrows indicate the blue spots, present probably due to deposition of chromium on the Daphnia carapace. medium, this mechanism does not appear to be the main cause of the toxicity of $\mathrm{Cr}_{2} \mathrm{O}_{3}$ NPs. The $\mathrm{Cr}_{2} \mathrm{O}_{3}$ NPs were approximately two times more toxic than chromium salt indicating that the characteristics of NPs, such as its reduced size, has an important influence on the toxicity observed. In view of the wide use of these NPs and their release into the environment, further ecotoxicological studies of these materials are required, mainly of chromium NPs, due scarce ecotoxicological data.

\section{ACKNOWLEDGEMENTS}

The authors acknowledge the Conselho Nacional de Desenvolvimento Científico e Tecnológico (CNPq - Proj. n 552112/2011-9) and Coordenação de Aperfeiçoamento de Pessoal de Nível (CAPES - Proj. n017/2009) for financial support and LCME/UFSC for support on TEM analysis. We also thank to Dr. G.A. Umbuzeiro for the use of the Laboratory of Ecotoxicology and Environmental Microbiology for performing the toxicity tests. K.P. Tavares thanks CAPES for the scholarship granted.

\section{REFERENCES}

ANNARAO, S., GURBANI, D., JAYALAKSHMI, K., SINHA, N., PARMAR, D., DHAWAN, A. \& KHETRAPAL, C.L. 2008. Chromium oxide nanoparticle distribution: an MRI study in rats. Proc. Intl. Soc. Mag. Reson. Med., 16: 2583.

ARAUCO, L.R.R., CRUZ, C. \& MACHADO-NETO, J.G. 2005. Efeito da presença de sedimento na toxicidade aguda do sulfato de cobre e do triclorfon para três espécies de Daphnia. Pesticidas: r. ecotoxicol. e meio ambiente, 5: 55-64.

ARTAL, M.C., HOLTZ, R.D., KUMMROW, F., ALVES, O.L. \& UMBUZEIRO, G.A. 2013. The role of silver and vanadium release in the toxicity of silver vanadate nanowires toward Daphnia similis. Environ. Toxicol. Chem., 32(4): 908-912. http://dx.doi.org/10.1002/etc. 2128

ARUOJA, V., DUBOURGUIER, H.C., KASEMETS, K. \& KAHRU, A. 2009. Toxicity of nanoparticles of $\mathrm{CuO}, \mathrm{ZnO}$ and $\mathrm{TiO}_{2}$ to microalgae Pseudokirchneriella subcapitata. Sci. Total Environ., 407: 1461-1468. http://dx.doi.org/10.1016/j. scitotenv.2008.10.053

ABNT - Associação Brasileira de Normas Técnicas. 2009. NBR 12.713 - Ecotoxicologia aquática - Toxicidade aguda - Método de ensaio com Daphnia spp (Cladocera, Crustacea).

BAÑOBRE-LÓPEZ, M., VÁSQUEZ-VÀSQUEZ, C., RIVAS, J. \& LÓPEZ-QUINTELA, M. A. 2003. Magnetic property of Chromium (III) oxide nanoparticles. Nanotechnology, 14: 318322.http://dx.doi.org/10.1088/0957-4484/14/2/342

BAUDO, R. 1987. Ecotoxicological testing with Daphnia. Instituto Italiana diidrobiologia, 45: 461-482.

BERTOLETTI, E., NIPPER, M.G. \& MAGALHÃES, N.P. 1992. A precisão de testes de toxicidade com Daphnia. AMBIENTE, 6: 55-59.

BLINOVA, I., IVASK, A., HEINLAAN, M., MORTIMER, M. \& KAHRU, A. 2010. Ecotoxicity of nanoparticles of $\mathrm{CuO}$ and $\mathrm{ZnO}$ in natural water. Environ. Pollut., 158(1): 41-47. http://dx.doi. org/10.1016/j.envpol.2009.08.017

BUFFET, P.E., TANKOUA, O.F., BERHANU, D., HERRENKNECHT, C., POIRIER, L., AMIARD-TRIQUET, C., AMIARD, J.C., BÉARD, J.B., RISSO, C., GUIBBOLINI, 
M., ROMÉO M., REIP, P., VALSAMI-JONES, E. \& MOUNEYRAC,C. 2011. Behavioural and biochemical responses of two marine invertebrates Scrobicularia plana and Hediste diversicolor to copper oxide nanoparticles. Chemosphere, 84(1): 166-174. http://dx.doi.org/10.1016/j.chemosphere.2011.02.003

CALOTO-OLIVEIRA, A. 2007. Toxicidade de elementos-traço para consumidores primários na presença de exopolissacarídeos produzidos por organismos fitoplanctônicos (Chlorophyceae e Cianophyceae). Mestrado em Ciências da Engenharia Ambiental - Escola de Engenharia de São Carlos, Universidade de São Paulo, São Carlos, São Paulo, 183p.

CETESB (Companhia de Tecnologia de Saneamento Ambiental do Estado de São Paulo). 1994. Teste de toxicidade aguda com Daphnia similis Claus, 1876 (Cladocera, Crustácea). Método de Ensaio.

DAS, D., NATH, B.C., PHUKON, P. \& DOLUI, S.K. 2013. Synthesis and evaluation of antioxidant and antibacterial behavior of $\mathrm{CuO}$ nanoparticles. Colloids Surf. B Biointerfaces, 101: 430-433. http://dx.doi.org/10.1016/j.colsurfb.2012.07.002

DU, X.S., XIAO, M. \& MENG, Y.Z. 2004. Facile synthesis of highly conductive polyaniline/graphite nanocomposites. Eur. Polym. J., 40:1489-1493. http://dx.doi.org/10.1016/j. eurpolymj.2004.02.009

El-TRASS, A., EL-SHAMY, H., EL-MEHASSEB, I. \& ELKEMARY, M. 2012. CuO nanoparticles: Synthesis, characterization, optical properties and interaction with amino acids. Appl. Surf. Sci.,258: 2997-3001. http://dx.doi. org/10.1016/j.apsusc.2011.11.025

GABBAY, J., BORKOW, G., MISHAL, J., MAGEN, E., ZATCOFF, R. \& SHEMER-AVNI, Y. 2006. Copper oxide impregnated textiles with potent biocidal activities. J. Ind. Text., 35(4): 323335. http://dx.doi.org/10.1177/1528083706060785

GIBOT, P. \& VIDAL, L. 2010.Original synthesis of chromium (III) oxide nanoparticles. J. Eur. Ceram. Soc., 30(4): 911-915. http:// dx.doi.org/10.1016/j.jeurceramsoc.2009.09.019

GRIFFITT, R.J., HYNDMAN, K., DENSLOW, N.D. \& BARBER, D.S. 2009. Comparison of molecular and histological changes in zebrafish gills exposed to metallic nanoparticles. Toxicol. Sci., 107(2): 404-415. http://dx.doi.org/10.1093/toxsci/kfn256

HAMILTON, M.A., RUSSO, R.C. \& THURSTON, R.V. 1977. Trimmed Spearman-Karber method for estimating median lethal concentration in toxicity bioassays. Environ. Sci. Technol., 11(7): 714-719. Correction: 1978, 12: 417.

HANNA, S.K., MILLER, R.J., ZHOU, D., KELLER, A.A. \& LENIHAN, H.S. 2013. Accumulation and toxicity of metal oxide nanoparticles in a soft-sediment estuarine amphipod. Aquat.Toxicol., 142-143: 441-446. http://dx.doi.org/10.1016/j. aquatox.2013.09.019

HEINLAAN, M., IVASK, A., BLINOVA, I., DUBOURGUIER, H.C. \& KAHRU, A. 2008. Toxicity of nanosized and bulk $\mathrm{ZnO}, \mathrm{CuO}$ and $\mathrm{TiO} 2$ to bacteria Vibrio fischeri and crustaceans Daphnia magna and Thamnocephalus platyurus. Chemosphere, 71(7): 1308-1316. http://dx.doi.org/10.1016/j. chemosphere.2007.11.047

HORIE, M., NISHIO, K., ENDOH, S., KATO, H., FUJITA K., MIYAUCHI, A., NAKAMURA, A., KINUGASA, S., YAMAMOTO, K., NIKI, E., YOSHIDA, Y., IWAHASHI, H. 2011. Chromium (III) oxide nanoparticles induced remarkable oxidative stress and apoptosis on culture cells. Environ. Toxicol., 28(2): 61-75. http://dx.doi.org/10.1002/tox.20695

HUND-RINKE, K. \& SIMON, M. 2006. Ecotoxic effect of photocatalytic active nanoparticles ( $\mathrm{TiO} 2$ ) on algae and daphnids (8 pp). Environ. Sci. Pollut. Res., 13(4): 225-232. http://dx.doi. org/10.1065/espr2006.06.311
ISANI, G., FALCIONI, M.L., BARUCCA, G., SEKAR, D., ANDREANI, G., CARPENÈ, E. \& FALCIONI, G. 2013. Comparative toxicity of $\mathrm{CuO}$ nanoparticles and $\mathrm{CuSO} 4$ in rainbow trout. Ecotoxicol. Environ. Saf., 97: 40-46. http://dx.doi. org/10.1016/j.ecoenv.2013.07.001

KAHRU A., DUBOURGUIER, H.C., BLINOVA, I., IVASK, A. \& KASEMETS, K. 2008.Biotests and Biosensors for ecotoxicology of metal oxide nanoparticles: A mini review. Sensors, 8(8): 5153 5170. http://dx.doi.org/10.3390/s8085153

KAHRU, A. \& DUBOURGUIER, H.C. 2010.From ecotoxicology to nanoecotoxicology. Toxicology, 269(2-3): 105-119. http:// dx.doi.org/10.1016/j.tox.2009.08.016

KAHRU, A. \& IVASK, A. 2012.Mapping the dawn of nanoecotoxicological research. Acc. Chem. Res., 46(3): 823833. http://dx.doi.org/10.1021/ar3000212

KELLER, A.A., WANG, H., ZHOU, D., LENIHAN, H.S., CHERR, G., CARDINALE, B.J., MILLER, R. \& JI, Z. 2010.Stability and aggregation of metal oxide nanoparticles in natural aqueous matrices. Environ. Sci. Technol., 44(6): 1962-1967. http://dx.doi. org/10.1021/es902987d

KNIE, J.L.W. \& LOPES, E.W.B. 2004. Testes Ecotoxicológicos: Métodos, técnicas e aplicações. FATMA/GTZ, Florianópolis, $289 \mathrm{p}$.

LIN, S., ZHAO, Y., JI, Z., EAR, J., CHANG, C.H., ZHANG, H., LOW-KAM, C., YAMADA, K., MENG, H., WANG, X., LIU, R., POKHREL, S., MÄDLER, L., DAMOISEAUX, R., XIA, T., GODWIN, H.A., LIN, S. \& NEL, A.E. 2012. Zebrafish high $\square$ though put screening to study the impact of dissolvable metal oxide nanoparticles on the hatching enzyme, ZHE1. Small, 9(910): 1776-1785. http://dx.doi.org/10.1002/smll.201202128

MAKHLOUF, S.A., BAKRA, Z.H., AL-ATTARA, H. \& MOUSTAFAA, M.S. 2013.Structural, morphological and electrical properties of $\mathrm{Cr} 2 \mathrm{O} 3$ nanoparticles. Mater. Sci. Eng., 178: 337-343. http://dx.doi.org/10.1016/j.mseb.2013.01.012

MANUSADŽIANAS, L., CAILLET, C., FACHETTI, L., GYLYTE், B., GRIGUTYTĖ, R., JURKONIENĖ, S. \& FÉRARD, J.F. 2012. Toxicity of copper oxide nanoparticle suspensions to aquatic biota. Environ. Toxicol. Chem., 31(1): 108-114. . http://dx.doi. org/10.1002/etc.715

MASSAROTTI, V., CAPSONI, D., BINI, M., ALTOMARE, A. \& MOLITERNI, A.G.G. 1998. X-ray powder diffraction ab initio structure solution of materials from solid state synthesis: the copper oxide case. Zeitschrift für Kristallographie,213: 259-265. http://dx.doi.org/10.1524/zkri.1998.213.5.259

MAURER-JONES, M.A., GUNSOLUS, I.L., MURPHY, C.J. \& HAYNES, C.L. 2013.Toxicity of engineered nanoparticles in the environment. Anal. Chem., 85(6): 3036-3049. http://dx.doi. org/10.1021/ac303636s

MELEGARI, S.P., PERREAULT, F., COSTA, R.H.R., POPOVIC, R. \& MATIAS, W.G. 2013. Evaluation of toxicity and oxidative stress induced by copper oxide nanoparticles in the green alga Chlamydomonas reinhardtii. Aquat. Toxicol., 142: 431-440. http://dx.doi.org/10.1016/j.aquatox.2013.09.015

OBERDÖRSTER, G., KANE, A.B., KLAPER, R.D. \& HURT, R.H. 2013. Nanotoxicology. In: Klaassen, C.D. (ed), Casarett and Doull's toxicology: The basic science of poisons. New York: McGraw-Hill, pp. 1189-1229.

PASCHOALINO, M.P., MARCONE, G.P. S. \& JARDIM, W.F. 2010. Os nanomateriais e a questão ambiental. Quim. Nova, 33(2): 421-430. http://dx.doi.org/10.1590/S0100-40422010000200033

PERREAULT, F., POPOVIC, R. \& DEWEZ, D. 2014. Different toxicity mechanisms between bare and polymer-coated copper oxide nanoparticles in Lemna gibba. Environ. Pollut., 185: 219227. http://dx.doi.org/10.1016/j.envpol.2013.10.027 
RODGHER, S., ESPÍNDOLA, E.L.G. \&LOMBARDI,A.T. 2010. Suitability of Daphnia similis as an alternative organism in ecotoxicological tests: implications for metal toxicity. Ecotoxicology, 19:1027-1033. DOI 10.1007/s10646-010-0484-1

SOUSA, V.S. \& TEIXEIRA, M.R. 2013. Aggregation kinetics and surface charge of $\mathrm{CuO}$ nanoparticles: the influence of $\mathrm{pH}$, ionic strength and humic acids. Environ. Chem., 10(4): 313-322. http://dx.doi.org/10.1071/EN13001
USEPA (Environmental Protection Agency). 1980. Ambient water quality criteria for chromium. EPA 440/5-80-035. EPA, Office of Water Regulations and Standards, Washington, D. C.

VAJPAYEE, P., KHATOON, I., PATEL, C.B., SINGH, G., GUPTA, K.C. \& SHANKER, R. 2011. Adverse effects of chromium oxide nano-particles on seed germination and growth in Triticumaestivum.J. Biomed. Nanotechnol., 7(1): 205-206. http://dx.doi.org/10.1166/jbn.2011.1270 